\title{
THE USE OF MOTORBIKE AS A MEANS OF GOOD TRANSPORTATION IN GRAB EXPRESS SERVICE AS SEEN FROM THE TRANSPORTATION LAW
}

\author{
Hilda Yunita Sabrie \\ (Dosen Departemen Hukum Bisnis, Fakultas Hukum Universitas Airlangga. Memperoleh gelar Sarjana Hukum (S.H.) dari \\ Universitas Airlangga (2008), Magister Hukum (M.H.) dari Universitas Airlangga (2013)) \\ (E-mail: hilda.sabrie@ fh.unair.ac.id)

\section{Dina Kusuma Ratih} \\ (Memperoleh gelar Sarjana Hukum (S.H.) dari Universitas Airlangga (2017), sedang menempuh S2 Magister Hukum di \\ Universitas Airlangga) \\ (E-mail: diraakusuma@gmail.com)
}

\section{Prawitra Thalib}

(Dosen Departemen Hukum Bisnis, Fakultas Hukum Universitas Airlangga. Memperoleh gelar Sarjana Hukum (S.H.) dari Universitas Jambi (2007), Magister Hukum (M.H.) dari Universitas Jambi (2009), dan Doktor (Dr.) dari Universitas Airlangga (2013)) (E-mail: prawitra@fh.unair.ac.id)

Received: 21 Februari 2018; Accepted: 28 Agustus 2018; Published: 19 September 2018

\begin{abstract}
:
The demand for goods delivery services in Indonesia is very large. Through this service, an item can easily move from one location to another and can be utilized so that the item has more value. Freight forwarding services can not be separated from the role of motor vehicles used as a means of transport. When viewed from the classification of its type, motor vehicles consist of motorcycles, passenger cars, freight cars, bus cars and special vehicles. In the relevant regulations stipulate that the goods delivery service must be carried out using the goods car. The obligation to use the goods car that has been regulated by law is not without reason. By using freight cars, bad weather factors and shock factors due to damaged road conditions can be avoided. This can minimize the risk of damage to the goods. But in practice it is often found that the delivery of goods is done using another mean of transporation that is motorcycle. The use of motorcycles is considered more effective and efficient because it can reach even remote areas. Although assessed so, the use of motorcycles can not avoid if there are two factors as mentioned above. Then this can lead to the risk of damage to the goods. Meanwhile, the delivery of goods must be implemented properly so that the goods can be saved and secured to the destination.
\end{abstract}

Keywords: Delivery of goods, Car Goods, Motorcycle, Goods Damage.

\section{Introduction}

The transportation activities, in fact has a function to facilitate the movement of a subject or object from a place to other destinations made through 


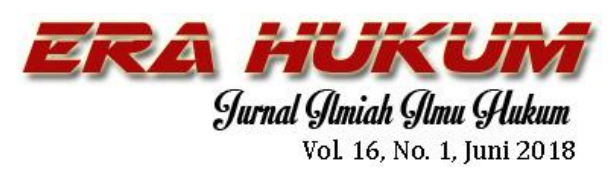

waters, land and air to reach the entire scope and region. ${ }^{1}$ Considering the transportation function is very useful, of course, it must be supported by good means of transportation. The transportation services should be available fairly evenly and affordably for the purchasing power of the people. The transportation activities has a purpose. The main purpose is to deliver a good and / or a person from a place to another so as to increase the value of the goods and raise the quality of the person transported. ${ }^{2}$ The movements that occur in people as passengers, aiming for that person can arrive at the destination so that they can perform the required activities. While the movement of goods delivered by the sender will raises the value goods. Since from the movement, the transported goods can be utilized by the recipient in the place of destination.

If associated with current developments, there is a phenomenon that attracts the attention of the public, namely the existence of application-

1 Abdulkadir Muhammad, Hukum Pengangkutan Niaga, (Bandung: Citra Aditya Bakti, 1998), h.7. based transportation. One of the transportation service providers is Grab. Grab has developed its business business, one of which is using motorcycles as a means of public transportation. It is very popular in community. In addition to efficiency in terms of time, taxibike-based applications or online taxibike is also able to serve anytime with a fairly high coverage. This phenomenon becomes a promising employment. The secure and convenient service of the drivers makes the demand for these services more and more numerous and high enough that this could be a new job opportunity. One of the most excellent services is Grab Express.

Briefly, Grab Express is an instant messenger service prepared by Grab Indonesia to deliver goods and documents quickly without distance limitations. Grab Express is a small package delivery solution committed to deliver goods or documents more easily and quickly. Its sophisticated system

2 Soegijatna Tjakranegara, S.H., Hukum Pengangkutan Barang dan Penumpang, (Jakarta, Rineka Cipta), h.16. 


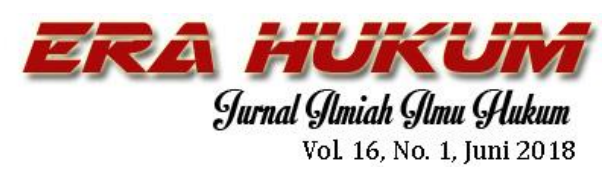

makes it easy for consumers to inform the full address and type of goods to be shipped, and monitor the location of the drivers during the delivery process.

There is a difference in the process of transporting goods using Grab Express with the carriage of goods on conventional expeditions. The difference lies in the use of conveyance. On the delivery of a conventional expedition, the main conveyor is a freight car. On delivery of goods using Grab Express, the goods are shipped using motorbikes as the main means of transportation. The delivery using a motorcycle is interesting activity. According to the applicable regulations, the delivery of goods must use freight cars as the main mode of transportation. Whereas, the effectiveness is the reason for the use of motorcycle as a mean of transportation on the delivery of goods. The delivery of goods must be sent quickly and on time. The destination of the shipped goods often has inadequate road access to be passed by the car. For example, for delivery of goods in villages and small roads, then the use of motorcycle will be more effective and reach the destination more easily.

With the implementation of this kind of transportation, it will directly affect the legal protection for the sender when using the Grab Express transportation. In the process of transporting goods is very possible if there is something undesirable things that cause the goods are not secured such as the goods are dissappear before reaching the destination or the goods are damaged partly or wholly. Goods that disappear before reaching the destination may be caused by factors lost, stolen, fell, burned and so forth. While, on the goods that are partially or completely damaged, even though the goods are exist and reachs the destination but the goods can not be used.

\section{Discussion}

\section{A. Principles of Goods}

\section{Transportation in Indonesia}

Transportation has become an important means of living. Transportation is always identical with the delivering activities and means of 


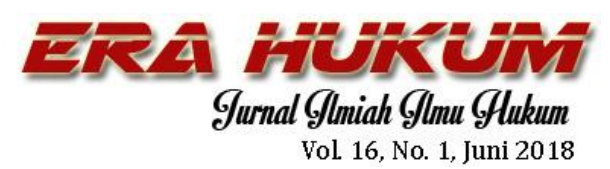

conveyance used. The conveyance is used as the main mode in implementing the transportation, so that transportation may occur. The transportation itself is the movement activity of the goods carried out using the means of conveyance. Here are some notions of transport according to experts:

\section{According to Sutan Usman Adji: ${ }^{3}$}

Transportation is the movement of the place of both objects and people, because the movement is absolutely necessary to achieve and improve the benefits and efficiency.

\section{According to H.M.N}

\section{Purwosutjipto:}

Transportation is a reciprocal agreement between the carrier and the sender in which the carrier binds to carry out the transportation of goods and / or persons from a place to a certain destination safely, while the sender binds himself to pay for the transport.

3 Sution Usman Adji dan Djoko Prasoko, Hukum Pengangkutan di Indonesia, (Rineka Cipta, Jakarta, 1990), h. 6.

\section{According to Soegijatna}

\section{Tjakranegara:}

Transportation is to move goods or commodity of goods and passengers from one place to another, so that the carrier produces transportation services or production services for the need of the community to the transfer or delivery of goods.

While the juridical definition of transportation has been regulated in UULLAJ and in PP 74 of 2014. Refer to some understandings of the transportation that has been exposed by experts and legislation, the notion of transportation in general is an activity of moving objects from a place to the destination using a mode of transportation. In this case, the intended object is a passenger or good that is sent. While the mode of transportation used may be motor and non-motorized vehicles within the scope of air, sea and land.

This research will focuses on the 


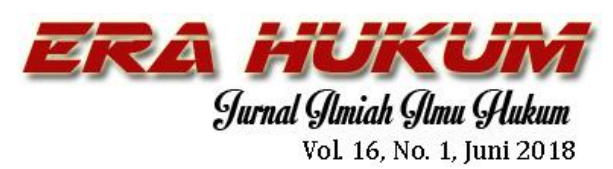

transportation of goods overland. The understanding of the goods in the context of the transportation of goods is a commodity or product that will meet a vehicle load enough to be treated as if it already meets a vehicle. ${ }^{4}$ Thus, when combined between the definition of transport and the definition of goods, the definition of goods transport is an activity of transfer of cargo as a transport object that has its own value for the owner by means of transport from a place to be transported to be delivered to the recipient in the place of destination. $^{5}$

In the delivery of any goods, there will arises a transport agreement in which the shippers with the conveyor agree to hold the implementation of the transportation of goods to be shipped. The agreement made will result a document as a sign of the emerge of the agreement.

Indeed in the nature of freight law, the existence of a transportation

${ }^{4}$ Yulia Budiarti, "Kedudukan Hukum PT Gojek Indonesia dalam Pelaksanaan Jasa Angkutan Berbasis Layanan Aplikasi Online GOSEND dan GOBOX", Tesis, Fakultas Hukum agreement made in writing is not the main requirement. Transportation may be carried out as long as the parties have agreed to carry out the transportation. However in the case of freight transportation, there is a necessity to make a transportation agreement. In Article 166 paragraph (3) jo. Article 168 of the UULLAJ, requires that in every carriage of goods shall be furnished with a transportation agreement and a cargo of goods. The enforcement of this obligation certainly has a ratio legis or a separate reason. With the transportation agreement made in writing, in addition to being the basis of the implementation of transportation, it can also be used as an evidence in case of default. Because in case of default, in this agreement also concerns the rights of others who have been violated. So with written agreement, the transportation agreement can be used as evidence.

In relation to the existence of these obligations, this has been regulated in

Universitas Muhamadiyah Yogyakarta, 2017, h. 33.

${ }^{5}$ Ibid. 
UULLAJ. In accordance with the applicable regulations concerning the transportation of goods, UULLAJ stipulates the goods transport document. The goods transport document shall be stipulated in Article 166 paragraph (3) of UULLAJ, which explains that the transportation of goods by general motor vehicle shall be equipped with documents covering the letter of transport agreement and the cargo of goods. Related to the transportation agreement, on the delivery of goods following the letter of transportation agreement in general. While liabilities related to cargo of goods have been regulated in Article 168 UULLAJ.

The cargo document is a letter made to reaffirm the agreement made between the carrier and the sender. In Article 168 UULLAJ also provides that in carrying goods, the cargo shall be made by public transportation companies as a travel document. This cargo document is subject to Article 90 of the Trade Code. In the cargo document usually consist of
1. Name of goods along with the type of goods and quantity of goods transported;

2. Contains information that the goods have been wrapped properly and safely;

3. Transportation charges on transported goods are shown;

4. The location of delivery destination.

\section{The Obligation to Use the Freigth Car} as The Goods Transportation

\section{Equipment}

With regard to the number of requests for paid transport services, this has been regulated in UULLAJ. The arrangements concerning paid transport services using vehicles are subject to UULLAJ, including the arrangements for modes of transportation in the delivery of persons and / or goods. According to Article 47 paragraph (3) UULLAJ, vehicles that can be used as general motor vehicles for the purposes of paid transport services for persons and / or goods only include passenger cars, bus cars and freight cars only. If it 


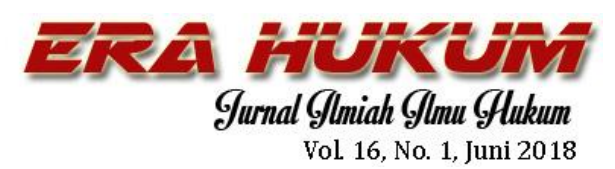

is viewed from the contents of the aforementioned article, then according to the law applicable for the transportation of goods by collecting fees on the transport shall be obliged to use the freight car as a means of conveyance.

Further, the regulation of the use of freight cars is also governed by UULLAJ Article 137 concerning the transportation of persons and goods. In Article 137 UULLAJ states that:

Further regulation of the use of freight cars is also governed by UULLAJ Article 137 concerning the transportation of persons and goods. In Article 137 UULLAJ states that:

(1) Transportion of persons and / or goods may use Motor and NonMotorized Vehicles.

(2) Transportation of persons using Motor Vehicles in the form of Motorcycle, Passenger Car, or bus.

(3) Transportation of goods with

Motor Vehicle shall use the freight car.

(4) Automobile goods are prohibited from being used for the transportation of persons, except: a. The ratio of Motor Vehicles to the transport of persons, geographical conditions and road infrastructure in provinces / regencies / municipalities is inadequate;

b. for the mobilization or training of the Indonesian National Army and / or the Police of the Republic of Indonesia; or

c. other interests based on the consideration of the Police of the Republic of Indonesia and / or the Regional Government.

(5) Further provisions concerning the freight cars used for the transportation of persons as referred to in paragraph (4) shall be regulated by government regulations.

It is reviewed from Article 137 paragraph (3) UULLAJ explaining that for the transportation of goods by using motor vehicles shall use the freight car. The obligation to use the freight car as the main means of transporting goods is not without reason. In the enactment of this law, the government must have thought carefully the reasons why the 


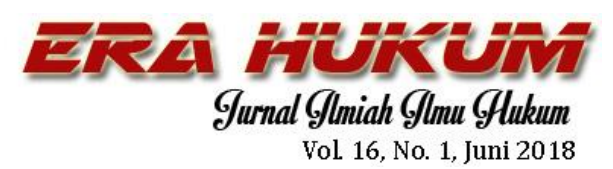

transportation of goods must be carried out by using the freight car. By using a freight car, the possibility of risk can be avoided. The goods sent using the freight car are safer and more secured, and also protected from danger, such as rain weather and environmental conditions such as damaged roads. The risks also that can be avoided if the goods are not wrapped properly, the delivery of goods using the freight is safer because when faced with environmental conditions such as road damaged, the goods are not exposed to excessive shocks.

The arrangement concerning the use of freight cars as a means of transporting goods is also regulated in Article 160 UULLAJ stating that the transportation of goods by public vehicles consists of public goods transportation and special freight transportation. The special freight transportation is a transportation which requires a freight car specially designed for transporting bulk, liquid, gas,

\footnotetext{
${ }^{6}$ Penjelasan Pasal 160 huruf (b) Undang Lalu
} Lintas Angkutan Jalan Nomor 22 Tahun 2009 container, plants, live animals, heavy equipment and carrying dangerous goods. ${ }^{6}$ The public goods transportation is the freight of goods in general, that are not dangerous and do not require special facilities of goods. ${ }^{7}$

Furthermore, in Article 161 UULLAJ regulates on the requirements in the transportation of public goods. The requirement is the road infrastructure that meets the requirements of the road class, the logistics distribution center and / or place for loading and unpacking and using the freight car. In such arrangements include several conditions in the implementation of freight transportation and these conditions are cumulative. Three points that become the condition of the transportation of public goods must be fulfilled so that the process of organizing the transportation more secure and safe. To this point, the UULLAJ that regulates the transportation of goods requires that the transportation of goods carried out must

\footnotetext{
7 Penjelasan Pasal 160 huruf (a) Undang Lalu Lintas Angkutan Jalan Nomor 22 Tahun 2009
} 


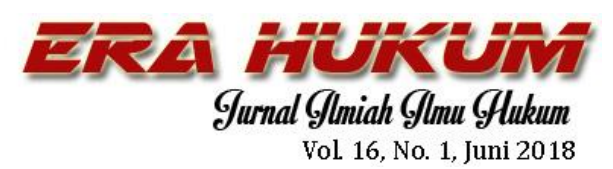

use the freight car.

However, in relation to the condition when the delivery of the goods is not transported using the freight car, in UULLAJ does not regulate the sanctions related. UULLAJ only stipulates that in the framework of the delivery of goods must use freight car. Whereas if the delivery of goods is not done using a freight car, in UULLAJ also does not regulate sanctions related to this matter.

\section{The Use of Motorcycles as Goods} Transportation According to Government Regulation Number $\mathbf{7 4}$ Year 2014

The publication of Government Regulation Number 74 Year 2014 on Road Transport (hereinafter referred to as PP 74/2014) is not without reason. PP $74 / 2014$ is published as an extension of the above legislation UULLAJ. As stated in UULLAJ, several articles contain the existence of government regulations. The existence of a government regulation organising on road transportation is as an extension of the arrangements that have not been regulated in UULLAJ. In PP 74/2014 there are several differences in the form of addition and subtraction between the existing rules on UULLAJ with the content of PP 74/2014 itself. The striking difference is the removal of special vehicles on the type of motor vehicle and the addition of a motorcycle as a means of conveyance in the cargo of goods. This is an interesting thing to discuss, because in the principle of legislation, it is obliged in the issuance of the regulation that must adjust the rules applying on it. In the above rules, the position of the law is above the government regulations. So in practice, PP 74/2014 should not distort the things set in UULLAJ.

The first differences seen from both of these regulations is on PP 74/2014, special vehicles as motor vehicles have been abolished. In Article 3 of Government Regulation 74/2014 states that:

(1) Transport of persons and / or goods may use:

a. Motor vehicle; and

b. Non-Motorized Vehicles. 


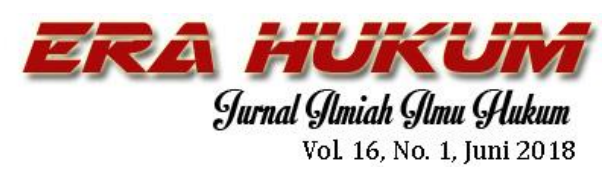

(2) Motor Vehicles as referred to in paragraph (1) letter a are grouped into:

a. motorcycle;

b. Passenger car;

c. Bus Car; and

d. Freight cars.

(3) Non-Motorized Vehicles as referred to in paragraph (1) letter $b$ shall include:

a. Vehicles driven by personnel; and

b. Vehicles drawn by animal power.

It can be seen in the regulation slightly contrary to Article 47 UULLAJ. In the UULLAJ setting, special vehicles enter the vehicle. While on PP 74/2014, there are no special vehicles in the group of motor vehicles.

The second difference lies in the use of motorcycles as a means of transportation. At UULLAJ, it is clearly explained before that goods transportation can only use the freight car. In Article 47 paragraph (3) UULLAJ also states that motorcycles are not included in vehicles that can be used for individual motor vehicles or public motor vehicles. In contrast to the
UULLAJ arrangement, in Article 3 PP $74 / 2014$ as noted above, motorcycles are not subject to restrictions on the use of individual and public motor vehicles.

In Article 10 of Government Regulation 74/2014 regulating the transportation of goods using motor vehicles states that motorcycles can be used as conveyance means as long as they meet the requirements contained therein. The contents of Article 10 are as follows:

(1) Transportation of goods using Motor Vehicles as referred to in Article 3 paragraph (1) letter a shall use Car of Goods.

(2) In the case of meeting technical requirements, Transportation of goods with Motor Vehicles as referred to in paragraph (1) may use Passenger Car, Bus Car, or motorcycle.

(3) The technical requirements as referred to in paragraph (2) for passenger cars and bus cars include:

a. available specially designed loading and / or loading space;

b. goods transported in accordance with the cargo space; and 


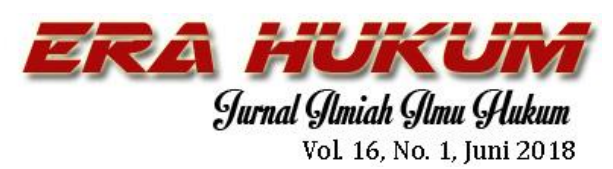

c. the quantity of goods transported does not exceed the carrying capacity in accordance with the type of vehicle.

(4) The technical requirements as meant in paragraph (2) for motorcycles include:

a. the load has a width not exceeding the handlebar;

b. the charge height does not exceed 900 (nine hundred) millimeters from the driver's seat; and

c. goods are placed behind the driver.

As written in Article 10 paragraph (1) of Government Regulation 74/2014, the transportation of goods is obliged to use the freight car. In paragraph (2), when fulfilling technical requirements, the transportation of goods may be carried out using passenger cars, bus cars and motorcycles. With regard to the transportation of goods, the provisions of Article 11 of Government Regulation $74 / 2014$ shall be considered, where the transportation of goods carried by passenger cars, bus cars or motorcycles shall take into account the safety factor. According to Article 10, it is asserted that the use of passenger cars, bus cars, or motorcycles as a means of conveyance is permitted with the provision obliged to fulfill technical requirements. For technical requirements, the use of motorcycles as a means of transporting goods shall be provided for in Article 10 paragraph (4) stating that the technical requirements for motorcycles include cargo having a width not exceeding the handlebar, the charge does not exceed 900 (nine hundred) millimeters from the driver's seat and the cargo is placed behind the driver.

But in the delivery of goods must also consider the nature of the goods to be sent. If the goods being transported are of special nature, it shall be subject to the provisions of Article 53 of Regulation 74/2014 that the transport of special goods shall be transported using a specially designed car in accordance with the nature and shape of the goods transported. Whereas for general goods transport, according to the provisions of Article 52 of Government Regulation 


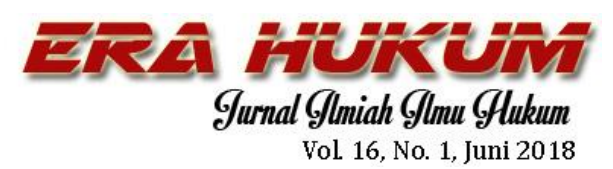

74/2014, public goods are generally non-hazardous goods and do not require special facilities. Thus, in addition to passenger cars and bus cars, motorcycles are also included in the mode of transportation that can be used to transport goods from one place to the destination in the road traffic space as long as the goods shipped are general goods.

This is supported by the revocation of the Minister of Transportation's letter. Previously issued Letter of the Minister of Transportation Number UM.302 / 1/21 / Phb / 2015 About Prohibition of Personal Vehicles (Motorcycles, Passenger Cars, Car Goods) Used To Transport People and / or Goods By Picking Up. The letter was addressed to the Chief of the Indonesian National Police (Kapolri) dated November 9, 2015. The Minister of Transportation revoked the ban on online transport operations. This statement was given considering the inadequacy of public transportation available to meet the needs of the community. Indirectly, this also applies to all transportation services within
Grab Indonesia which use private vehicles including motorcycles, passenger cars and freight cars as the main means of transportation.

By legislation and also the revocation of the Minister of Transportation letter, confirmed that motorcycles may be used as a means of transporting goods. So it can be concluded related to the legality of the use of motorcycles as a means of transporting goods is not prohibited. The use of motorcycles can be carried out as long as it meets the three elements of the technical requirements as set forth in Article 10 number (4) PP 74/2014.

\section{The Shipping Mechanisms Using}

\section{Grab Express Services}

As laid down in PP 74/2014, motorcycles can be used as a means of conveyance of goods with a note must meet technical requirements. In addition, the use of motorcycles is also considered more effective and efficient for the delivery of goods because it can reach the destination more quickly. Along with the growth and development 
of technology finally led to a new innovation in the form of merging technology with the procurement of transportation services. Innovation in the form of vehicle booking services through applications on smart phones. So until now many emerging application service provider of transportation companies one of them is Grab Indonesia.

Grab Indonesia is a provider of vehicle booking services in Indonesia. Present in Indonesia since mid-2014, Grab Indonesia has carved its own history in the world of technology-based transportation. Starting from the application of taxi providers, booking cars and motorcycles at the beginning of its emergence, currently Grab Indonesia has widened the type of service. Stay on carrier service application carrier paths, now there are some new services. One of the most excellent services is Grab Express.

Grab Express is an express courier service or delivery service based on the application. Delivered goods can be packages and documents. The delivery using a motorcycle as a mode of transportation. The use of motorcycles as a mode of transportation in Grab Indonesia can be said to be more dominant than other modes of transportation. This is because the transportation activities in Grab Indonesia use more motorcycles, because the partner of Grab Indonesia on service by using motorcycle is bigger than those using car or taxi.

In the process of delivery of goods using Grab Express as already reviewed above, of course, involves several parties. As described above, the identifiable parties are shippers, recipients, drivers and Grab Indonesia. The parties must have their respective roles, duties and rights and obligations, which can be explained as follows:

1. Grab Indonesia. In the delivery of Grab Express goods, Grab Indonesia acts as a forwarder. This is because Grab Indonesia provides services but does not necessarily transport the shipment itself. Grab Indonesia seeks prospective shippers and / or 


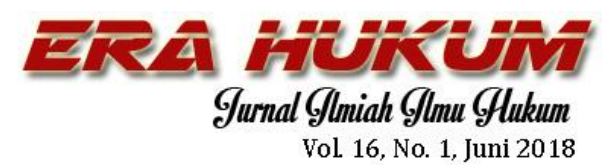

recipients of a driver's goods by random methods through the application. Grab Indonesia also guarantees that Grab Express service users will get a sender who has good faith in shipping by means of conveyance in the form of a motorcycle in accordance with the applicable provisions and ensure that the driver will deliver the goods safely and safely on arrival.

2. Driver, assigned to deliver the package. The role of the Grab Express driver when associated with the party in the carrier is as a carrier. In Article 91 of the Trading Code, the primary obligation of the carrier is to carry the transport from place to place of destination. So the Grab Express driver is obliged to organize freight forwarding and is also obliged to maintain the safety of the
Hilda Yunita Sabrie, Dina Kusuma Ratih

\& Prawitra Thalib The Use of Motorbike...

goods it is transporting to the destination according to the transport agreement.

3. Shipper. Both parties act as consumers of Grab Express services. As a user of freight service, the sender is obligated to pay the shipping cost as a form of exchange of achievement from the implementation of the transport itself. This obligation only arises if agreed upon first, because according to Article 491 Trading Code, the obligation to pay the transportation money is on the recipient after the goods received. In the event of a loss or damage, the sender shall be entitled to indemnification.

After discussing the parties involved in the Grab Express service, each of them has a legal relationship. The legal relationship between the 


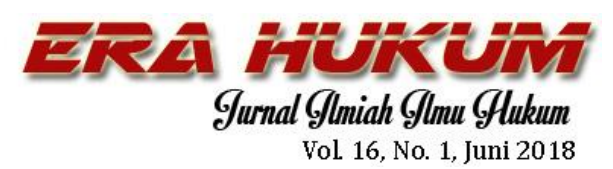

carrier, the sender and the receiver can

be illustrated by the following charts:

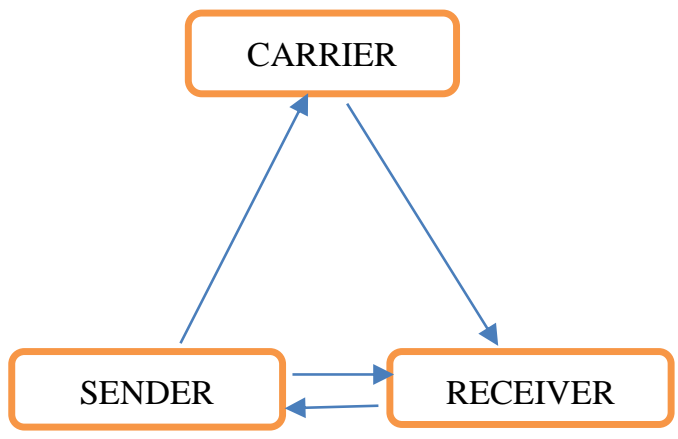

Chart 1.

Legal Relationship the Carrier, the Sender and the Receiver

Through this chart, the legal relationship that arises in a coherent manner is the delivery of goods to the carrier, then the carrier to the recipient of the goods. In relation to the fulfillment of obligations, the sender shall be obliged to pay a fee for the transportation services carried by the carrier. The obligation of the carrier itself is to carry out the transportation of goods sent by the sender to the destination ie to the recipient. then the recipient is obliged to receive the goods that have been delivered. The right of the recipient is to obtain goods in good condition, safe and secure, or at least equal to the original condition when the goods are shipped. Should there be any damage to the goods, the sender can not necessarily hold accountable to the carrier. Because in this case, the carrier has only a legal relationship with the freight forwarder to carry out the transport. So the party who can hold the responsibility is the sender of the goods to the carrier.

In the process of transportation is certainly there are factors that can cause the goods are not safe, especially the delivery is done using a motorcycle. In this case there must be a party that gives accountability. Responsibility by the carrier includes various aspects. Judging from the nature of accountability, the carrier must perform prevetif action and repressive action. Preventive action on the transport itself must be done, where the carrier take precautions in order to avoid errors in transportation that resulted in damage to the goods. Furthermore, the carrier must also perform repressive actions as a manifestation of liability for damage to the goods that occur. Action that can be done is by providing compensation to 


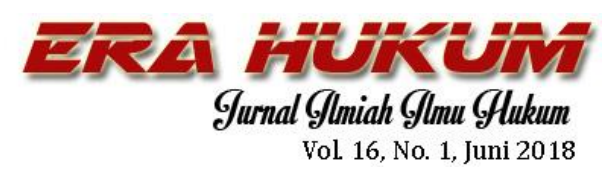

the consumer as a form of responsibility of the carrier.

This means that Grab Indonesia is represented by Grab Express drivers responsible from the receipt of the goods until the goods are delivered at the receiving end. If the transportation of goods is not safe and safe, then this is also the responsibility of the carrier. Where in this case, the carrier is Grab Indonesia which is represented by the Grab Express driver.

According to the official guidelines on the use of Grab Express services that can be accessed through the official website of Grab Indonesia, it arrange related to several important things in the delivery, as follows:

\section{Delivery by motorcycle using canvas bag}

The main purpose with the use of this canvas bag is that the items delivered can arrive at the destination safely and securely. As for when not using a canvas bag, drivers are required

\footnotetext{
${ }^{8}$ Baca Ketentuan Umum Penyelenggaran Grab Express.
}

\section{Hilda Yunita Sabrie, Dina Kusuma Ratih \\ \& Prawitra Thalib The Use of Motorbike...}

to tie the goods with a motor hook strap.

\section{Type of goods that can be shipped with Grab Express}

On the delivery of goods, there are several types of goods that can delivered using Grab Express, there are a package with medium size, wreaths, raincoats, dried food wrapped neatly, groceries and clothes. Grab Indonesia also has the recommended items not to ship using these services: live animals, jewelry, sharp weapons, money, securities, narcotics and goods prohibited by law. Thus, a package which may contain goods prohibited by the terms of delivery and hereby reserves the right to refuse acceptance and delivery of any package of goods which in its opinion can not be transmitted safely or unlawful. $^{8}$

\section{Size of items that can be shipped}

In practice, Grab Indonesia has a provision that packets shipped weigh no more than five kilograms or a maximum 


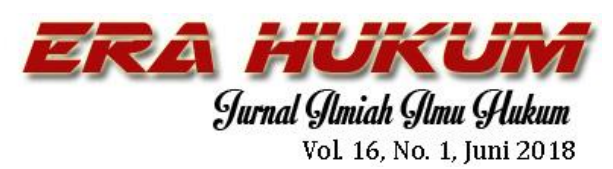

weight of five kilograms package. In addition, the provisions on the size of the delivered package is with dimensions of maximum length of 25 centimeters, maximum width of 32 centimeters and maximum height of 12 centimeters.

\section{Insurance coverage on each item shipped}

As has been written on the official website of Grab Indonesia, consumers do not have to worry about the goods will be damaged. Grab Indonesia Party has guaranteed that on every shipment of goods using Grab Express get insurance coverage up to $\mathrm{Rp}$ 10.000.000, - (ten million rupiah). The granting of this guarantee is as a form of protection for consumers.

Related to the four terms concerning the provisions of the delivery mechanism on the Grab Express service, on the first to third points can be said in accordance with the technical requirements of motorcycle usage. Technical requirements for the use of motorcycles as a means of transporting goods as stipulated in Article 10 paragraph (4) PP 74/2014). The requirements of that article have been applied by Grab Indonesia through the provisions as described above.

\section{Conclusion}

The implementation of goods transportation in Indonesia is implemented based on UULLAJ and PP 74/2014. Related legality in UULLAJ not organize the use of motorcycles as a means of conveyance of goods. In Article 47, Article 137 and Article 161 UULLAJ, stipulates that the transportation of goods shall be carried out using a freight car as a means of conveyance. But in PP 74/2014 states that motorcycles can be used as a means of transporting goods. It is regulated in Articles 10 and 11 of Government Regulation 74/2017, stating that the transportation of goods using motorcycles is not prohibited as long as it meets technical requirements and takes into account the safety factor. The new arrangement in PP 74/2014 is a development of UULLAJ. The use of 


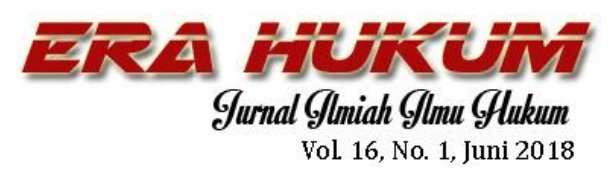

motorcycles as a means of transporting goods is done to facilitate the needs related to the efficiency and effectiveness of the delivery of the goods themselves. The terms of the goods delivery mechanism in the Grab Express service are in compliance with applicable regulations. In its provisions set related to the limitation of the type and size of goods that can be shipped as well as the obligation to use the canvas bag behind the driver to make the goods safer. This enforcement complies with the technical requirements set out in Article 10 paragraph (4) of Government Regulation 74/2014.

\section{BIBLIOGRAPHY}

\section{A. Regulation}

Kitab Undang-Undang Hukum Dagang

(Wetboek Van Koophandel).

Kitab Undang-Undang Hukum Perdata (Burgerlick Wetboek).

Undang-Undang Republik Indonesia Nomor 8 Tahun 1999 Tentang

Perlindungan Konsumen

Undang-Undang Republik Indonesia

Nomor 22 Tahun 2009 Tentang Lalu Lintas dan Angkutan Jalan
Hilda Yunita Sabrie, Dina Kusuma Ratih

\& Prawitra Thalib The Use of Motorbike...

Undang-Undang Republik Indonesia Nomor 12 Tahun 2011 Tentang Pembentukan Peraturan

Perundang-Undangan

Undang-Undang Republik Indonesia Nomor 40 Tahun 2014 Tentang Perasuransian

Peraturan Pemerintah Republik Indonesia Nomor 74 Tahun 2014 Tentang Angkutan Jalan

\section{B. Books}

Adji, Sution Usman dan Djoko Prakoso, Hukum Pengangkutan di Indonesia, Djambatan, Jakarta, 2008.

Ali, A Hasyimi, Pengantar Asuransi, Bumi Aksara, Jakarta, 1995.

Marzuki, Peter Mahmud, Penelitian Hukum, Kencana, Jakarta, 2005.

Muhammad, Abdulkadir, Hukum Pengangkutan Niaga, Citra Aditya Bakti, Bandung, 1998.

Mulhadi, Dasar Dasar Hukum Asuransi, Rajawali Pers, Depok, 2017.

Purwasutjipto, H.M.N, Pengantar Pokok Hukum Dagang Indonesia, Rineka Cipta, Jakarta, 1990. 


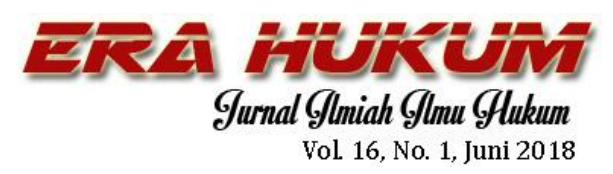

Sembiring, Sentosa, Hukum Asuransi, Nuansa Aulia, Bandung, 2014.

Soekanto, Soejono dan Sri Mamuji, Penelitian Hukum Normatif: Suatu Tinjauan Singkat, Rajawali, Jakarta, 1985.

Subekti, Aneka Perjanjian, Citra Aditya Bakti, Bandung, 1995.

Tjakranegara, Soegijatna, Pengangkutan Barang dan Penumpang, Rineka Cipta, Jakrta, 1996.

Wardana, Kun Wahyu, Hukum Asuransi: Proteksi Kecelakaan Tranportasi, Maju Mundur, Bandung, 2009

Wijaya, Andika, Aspek Hukum Bisnis Transportasi Online, Sinar Grafika, Jakarta, 2016.

\section{Journals}

Hendratno, Edi Toet, "Masalah Transportasi Kota Dilihat Dengan Pendekatan Hukum, Sosial dan Budaya", Mimbar Hukum, Volume 21 Nomor 3, 2009.

Sabrie, Hilda Yunita, "Karakteristik Hubungan Hukum dalam Asuransi Jaasa Raharja Terhadap Klaim Korban Kecelakaan Angkutan Umum", Yuridika, Volume 30 Nomor 3, 2015.
Hilda Yunita Sabrie, Dina Kusuma Ratih

\& Prawitra Thalib The Use of Motorbike...

Susanto, Heru, "Subrogasi sebagai Bentuk Pertanggungjawaban Pihak Ketiga Terhadap Penanggung dalam Perasuransian" Dialektika, Volume 5 Nomor 1, 2007.

\section{Thesis}

Budiarti, Yulia, "Kedudukan Hukum PT Gojek Indonesia dalam Pelaksanaan Jasa Angkutan Berbasis Layanan Aplikasi Online GOSEND dan GOBOX', Tesis, Fakultas Hukum Muhamadiyah Yogyakarta, 2017.

\section{E. Essays}

Mustofa, Ega, "Tanggungjawab Pengangkut terhadap Barang Bagasi dalam Pengangkutan Darat", Skripsi, Fakultas Hukum Universitas Airlangga, 2011.

Wihapsoro, Aulia Panji, "Tanggungjawab Pengangkut atas keterlambatan dan/atau Kerusakan dalam Pengiriman Paket Barang Jalur Darat" Skripsi, Fakultas Hukum Universitas Negeri Semarang, 2010.

\section{F. Newspaper}

Admin, "Menteri Perhubungan Cabut Lagi Larangan Ojek Online", Tabloid Bintang, Edisi 18 Desember 2015. 


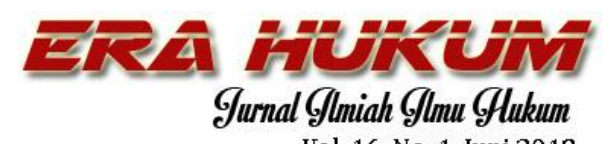

Vol 16, No. 1, Juni 2018

G. Internet

Admin, "Isi Surat Menteri Johan ke Kapolri Terkait Gojek dkk", Hukum Online, http://www.hukumonline.com/b erita/baca/lt56737426110fb/inisurat-menteri-ignasius-jonanke-kapolri-terkait-go-jek-dkk, 18 Desember 2015, dikunjungi pada 24 November 2017.

Admin, "Layanan Grab Express", http://www.grab.com/id/, $\quad 17$ Agustus 2017, dikunjungi pada tanggal 5 November 2017.

Admin, "Inscurance Definition", http://www.allenins.com/Inscur ance Definitions.html, dikunjungi pada tanggal 27 November 2017.

Novita, Nifa, "Profil Singkat Grab", http://nitanovitasr.blogspot.co.i d/2016/10/profil-singkatgrab.html, 10 November 2016, dikunjungi pada tanggal 19 Oktober 2017.

Rusman, Ignatius, Prinsip Kontribusi,http://www.akademi asuransi.org/2012/09/prinsipkontribusi_18.html, dikunjungi pada tanggal 27 November 2017.

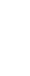

Hilda Yunita Sabrie, Dina Kusuma Ratih

\& Prawitra Thalib The Use of Motorbike...

\section{H. Dictionaries}

Kamus Besar Bahasa Indonesia

The Black Law Dictionary 